\title{
Environmental Learning with Inquiry Method in Tondano Lake
}

\author{
Treesje Katrina Londa* \\ Fakultas MIPA \\ Universitas Negeri Manado \\ Manado, Indonesia \\ *treesjelonda@unima.ac.id
}

\author{
Felly Ferol Warouw \\ Fakultas Teknik \\ Universitas Negeri Manado \\ Manado, Indonesia \\ ferolwarouw@unima.ac.id
}

\author{
J.G.N. Nusa \\ Fakultas Pascasarjana \\ Universitas Negeri Manado \\ Manado, Indonesia \\ jgnnusa@unima.ac.id
}

\begin{abstract}
Learning Environment by using the Inquiry method can bring students into problems directly, so they can develop capabilities in terms of solving environmental problems that will be faced. In addition, the Inquiry method will train students to communicate well between fellow students and teachers (lecturers). The application of inquiry methods is effective in increasing students' competency of the environment and would be skilled in solving problems. By investigations conducted at Tondano Lake, students will be able to prove the truth of a theory by themselves. This type of research is an experiment using descriptive quantitative data analysis techniques by one group pretest-posttest design. This research is intended to describe the presence or absence of a treatment given to the subject of the study. Based on the results of the research and discussion, it was concluded that environmental learning using the inquiry method at Tondano Lake had a significant effect on students' competency. This is evidenced by the average gain score reaching 92.4769 or $94.5 \%$ and the implementation of learning which is in the effective category.
\end{abstract} lake

Keywords: learning, environment, inquiry method, tondano

\section{INTRODUCTION}

The main goal in education is to bring students to be able to apply their thinking skills through experience not just by hearing information [1]. Good education should be able to show how students learn, remember, control what will be learned, so that they can learn from each other [2]. In higher education it is highly required to develop intellectual skills in collecting and analyzing data in solving problems [3]. They could identify and find solutions to problems given independently.

Environmental science subject at Science Education Department in Postgraduate UNIMA is in second semester. In general, this subject aim to provide an understanding of the environment and the problems also solutions for students in order to create a harmonious relationship between human activities and the environment.

The Environmental Sciences course seeks to instill insight into the environment so that students are able to: plan environmentally sound development, manage natural resources and the environment, preserve the energy resources needed for life, discuss current global and local environmental issues, and analyze the impact of development on ecological system or ecosystem. In other words, these subjects that are applied in science must be able to lead students to understand environmental problems both globally, nationally and locally, and be able to find solutions to these problems.

Broadly speaking, the subject matter of environmental science includes: basic principles of the environment, energy flow, material cycles, environmental and natural resource management, global warming, air / water / soil pollution, waste management, and analysis of environmental impacts. As the application of lecture material, students are given the task to review some of the actual environmental problems in the area while solving the problem. Then one of the expected abilities of the participants in this course is that students must be able to recognize local environmental problems and how to solve these problems. Students are directed to make a study of environmental problems in their surroundings and how to solve them.

The lake is a freshwater ecosystem that occupies the surface of the earth, which is formed naturally and surrounded by land, so its quality and quantity are strongly influenced by the upstream ecosystem of the watershed which directly affects the condition of the rivers entering the lake. Therefore, the management and use of lakes as a water source cannot stand alone, but must be integrated into watershed management as a regional unity. Lake ecosystems are multipurpose water 
resources, such as: hydropower energy sources, fish cultivation facilities, water sources for agriculture, sources of clean water, recreational facilities and tourism objects, research objects, microclimate guards, nuftah plasma sources [4].

The problem of lake ecosystems actually occurs because of the activities mentioned above. Water quality decreases due to fish food discharges, fertilizers for agricultural activities, solid and liquid waste due to recreational and tourism activities, in addition to waste due to local residents' household activities and waste disposal, suspension and dissolved solids that flow through the inlets of rivers or waterways which is around the lake. As a result, there has been an increase in eutrophication as a trigger for the growth rate of water hyacinth, hydrilla, algae and other aquatic plants, then its decay can be a cause of siltation and succession of the lake to become land (narrowing).

Utilization of irregular lake waters and beyond the carrying capacity of lake ecosystems, must be addressed with the right strategy. Anna J. Dare proposes several strategies that can be taken to achieve the objectives and overcome various problems of water resources [5].

To improve students understanding in studying environmental studies and problems and their solutions, one method can be chosen that is suitable. The success or failure of a learning process lies in using the method. Learning method is a very important component that must be mastered in delivering material or lessons to students. One effort to improve students' understanding of environmental education is by applying the inquiry method.

Inquiry according A. Klippel means a series of learning activities that involve maximally all students' abilities to search and investigate systematically, critically, logically, analytically, so that they can formulate their own findings confidently [6]. This is supported by J,N Tuma, who stated that one of the goals of teaching and educating is to foster critical thinking skills through the implementation of learning tasks [7]. According to Chabay the learning experience needs to be developed to form high-quality human beings, both mental, moral and physical [8]. The methods and strategies for teaching and learning that are conducive to this need to be developed, for example the method of inquiry, discovery, problem solving, and so on.

How can environmental learning improve the effectiveness of students' understanding of local environmental problems and their solution efforts using the inquiry method?

\section{METHODS}

\section{A. Types of Research}

This type of research is an experiment using descriptive quantitative data analysis techniques. The study design used one group pretest-posttest design. This research is intended to describe the presence or absence of a treatment given to the subject of the study. This design involves one group observed in the pre-test (O1) stage which is then followed by certain treatments $(\mathrm{X})$ and post-test (O2) [9].

\section{$\mathbf{O}_{1} \mathbf{X} \mathbf{O}_{2}$}

Information:

$\mathrm{O} 1=$ pre-test before being given treatment

$\mathrm{X}=$ class with contextual learning

$\mathrm{O} 2$ = post-test after being given treatment

The subjects of this study were all of the second semester Unima Postgraduate science education students who attended the 2018 environmental science courses totaling 18 people.

Data collection techniques used include: (1) observation methods to obtain learning implementation data; (2) the test method used to determine the development of student abilities before and after learning.

Data collection is a method carried out by researchers to obtain data, the type of data collected in this study is quantitative data, where data derived from the results of tests of student understanding both in the form of pretest and posttest. While the data sources used in this study are primary data and secondary data both obtained directly from students and from the education unit database.

The data analyzed in this study consisted of quantitative and qualitative data. Quantitative data obtained were analyzed using the percentage table and gain score. Qualitative data obtained at the time of observation were analyzed using meaningful narratives.

The learning outcome data in the form of a gain score were analyzed using the t-test analysis formula, with a significance level of 5\%. Data analysis is done using help from the SPSS for Windows application.

\section{B. Focus of Research}

The focus of research is basically how the main problem can be understood by researchers to find solutions to problem solving recommendations in the form of descriptions or calculation results. For this research, the focus is derived from the experience of researchers or through knowledge obtained from scientific literature or other literature. In detail the focus of this research is to:

- Identification of waste management policy products in the city of Manado.

- Analysis of the program for implementing the policy of developing the Manado City waste bank.

- Analyzing the factors that become obstacles and supporters in the waste bank development program in Manado City.

\section{RESULTS AND DISCUSSION}

\section{A. Data Description}

The data in this study are learning activities and student learning outcomes using inquiry methods. Student learning 
activities during learning using inquiry methods are obtained through observation sheets. Learning outcomes are obtained from the gain score or calculating the difference between the student's initial ability score (pretest) and the student's final ability (posttest) to test the hypothesis further. The description of the research results is as follows.

\section{B. Learning Activity of Students}

The researcher observes student learning activities during the learning process. Observation of activities is intended to observe student learning activities during the learning process by using inquiry methods. The observed activities include: (1) investigating the problem, (2) identifying the problem, (3) gathering information, (4) creating the work, (5) dividing the work, (6) evaluating the work. Observations were carried out for three meetings by the observer (observer) through the student activity observation sheet. The results of observations of student activities during learning are outlined in the form of a percentage of the following table 1 .

TABLE I. Percentage OF StUdent LeARNing Activities

\begin{tabular}{|l|l|l|l|}
\hline No & \multicolumn{1}{|c|}{ Meeting } & \multicolumn{1}{|c|}{$\begin{array}{c}\text { Percentage } \\
(\%)\end{array}$} & \multicolumn{1}{|c|}{ Information } \\
\hline 1. & I & 71 & Active enough \\
\hline 2. & II & 83 & Active \\
\hline 3. & III & 89 & Very active \\
\hline & Average & 81 & Active \\
\hline
\end{tabular}

Based on the percentage of results above, it can be seen that the categories of student learning activities for each meeting experienced a very good increase.

\section{Learning Outcomes}

The comparison of the average value of students' understanding of student environmental learning before and after using the inquiry method in learning can be seen in the following table 2 .

TABLE II. STUDENT LEARNING OUTCOMES

\begin{tabular}{|l|l|l|l|}
\hline Students & Pretest & Posttest & $\begin{array}{c}\text { N Gain } \\
(\%)\end{array}$ \\
\hline 1 & 1.6 & 3.85 & 93.75 \\
\hline 2 & 1.6 & 3.85 & 93.75 \\
\hline 3 & 1.2 & 3.85 & 94.64 \\
\hline 4 & 1.6 & 3.85 & 93.75 \\
\hline 5 & 1.2 & 3.75 & 91.07 \\
\hline 6 & 1.6 & 3.75 & 89.58 \\
\hline 7 & 1.6 & 3.75 & 89.58 \\
\hline 8 & 1.6 & 3.75 & 89.58 \\
\hline 9 & 2.4 & 3.85 & 90.63 \\
\hline 10 & 1.6 & 3.85 & 93.75 \\
\hline 11 & 2.4 & 3.85 & 90.63 \\
\hline 12 & 1.6 & 3.85 & 93.75 \\
\hline 13 & 1.6 & 3.8 & 91.67 \\
\hline 14 & 1.2 & 3.85 & 94.64 \\
\hline 15 & 1.6 & 3.9 & 95.83 \\
\hline 16 & 1.6 & 3.8 & 91.67 \\
\hline 17 & 1.2 & 3.85 & 94.64 \\
\hline 18 & 1.6 & 3.8 & 91.67 \\
\hline Average & 1.60 & 3.82 & 92.4769 \\
\hline & & & \\
\hline
\end{tabular}

The results showed that the effectiveness of environmental learning with the inquiry method in Tondano Lake was very good. This can be seen from the acquisition of the initial ability average $($ pre-test $)=1.60$ and the final ability (post-test $)=3.82$, which means that descriptively there are differences in learning outcomes achieved. The results of the $\mathrm{N}$-gain score calculation are 92.4769 , indicating that the inquiry method used in learning is included in the very effective category.

Achieving the effectiveness of optimal learning is inseparable from the implementation of learning in Tondano Lake which is an outdoor study. Students who study inside and outside the classroom are better than students who only study in class. This is because learning outside the classroom is more meaningful, because students are directly involved in the process of understanding concepts and also make the learning environment more enjoyable.

The implementation of environmental learning with inquiry methods in Tondano Lake requires students to be able to apply the theories, skills and techniques learned to solve problems that are close to students. Environmental problems around Tondano Lake that are real and relevant for student life are very suitable for study. Through direct observation, the development of students' problem solving skills will increase. For example, passing the investigation phase on observation and interview activities directly makes the data obtained more complete. Complete data makes the discussion made to be more detailed and valid, rather than making scientific papers based on information via the internet. This will affect students' attitudes, mastery of concepts, and critical thinking on environmental issues significantly, especially in Tondano Lake (see figure 1).

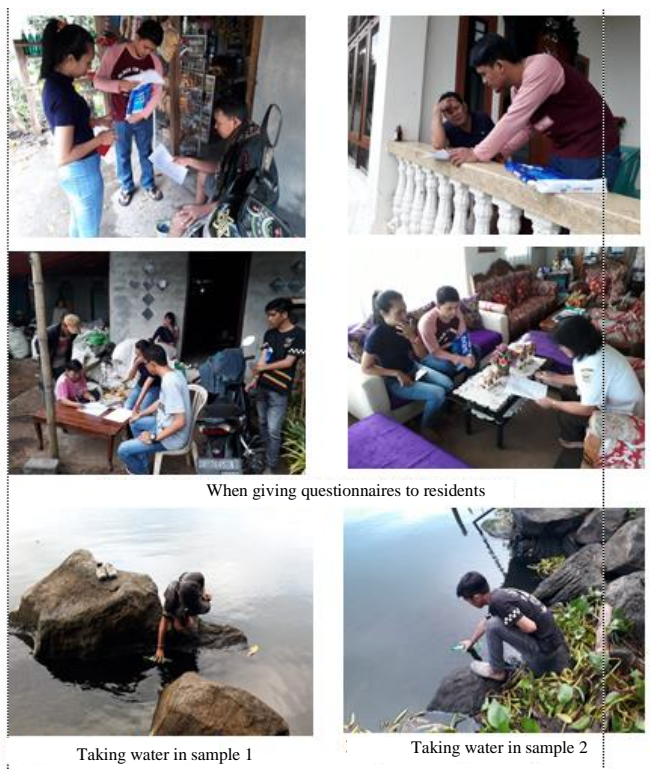

Fig. 1. Environmental Learning with Inquiry Method in Tondano Lake.

Improving student learning outcomes and student learning activities in learning using inquiry methods is a process that starts from confronting students with problems, guiding students to connect with concepts and finding interesting ideas 


\section{ACKNOWLEDGMENT}

related to problems, exploring or gathering various sources of information, identifying by building questions from interesting ideas and emphasizes the problem, students choose meaningful questions from information sources, create interesting understanding related to the problem, share the work with other students and finally evaluate the results of the discussion that has been done and draw conclusions related to the material taught.

Learning by using the inquiry method makes students more active in learning, because by applying the inquiry method, the knowledge acquired by students is not the result of remembering the facts but the results of finding themselves. The application of inquiry methods in learning also allows students to work together in groups. The level of understanding obtained by students is more in-depth because students are directly involved in the process of finding answers to existing problems and directly practice experiments related to subject matter so that the learning process is more effective and efficient.

\section{CONCLUSION}

Based on the results of the research and discussion, it can be concluded that environmental learning using the inquiry method in Tondano Lake has a significant effect on student understanding. This is evidenced by the average gain score reaching 92.4769 or $94.5 \%$ and the implementation of learning in the effective category. To optimize the learning process of environmental knowledge so as to use local environmental media as a means to develop knowledge about the environment. The use of method inquiry is also very suitable in the learning process because this method can make students explore creativity and critical thinking in solving a problem.
For these results, the author would like to thank all those who have participated in the implementation of this research. The author also thanked the Manado State University through the LPPM institution which provided funding support for this research. Thanks are also conveyed to the Manado City Government and the Community managing the garbage bank in Manado City, which has given the author the freedom to make observations in the field. Finally, we convey our thanks to the AES 2019 committee and parties related to this publication plan.

\section{REFERENCES}

[1] M. Bienkowski, E. Snow, D. Rutstein, and S. Grover, "Assessment design patterns for computational thinking practices in secondary computer science : a first look," SRI Educ., 2015.

[2] S. Turkle, "Talk to me: How to teach in an age of distraction," Chron. High. Educ., 2015.

[3] I.W. Widana, "Higher Order Thinking Skills Assessment towards Critical Thinking on Mathematics Lesson," Int. J. Soc. Sci. Humanit., 2018.

[4] W. Haeberli, Y. Schaub, and C. Huggel, "Increasing risks related to landslides from degrading permafrost into new lakes in de-glaciating mountain ranges," Geomorphology, 2017.

[5] M.O.P.A.I.C. MOP and IC, "Millennium development goals needs assessment," Development, 2005.

[6] A. Klippel, F. Hardisty, and R. Li, "Interpreting spatial patterns: An inquiry into formal and cognitive aspects of Tobler's first law of geography," Ann. Assoc. Am. Geogr., 2011.

[7] J.M. Tuma and J.M. Pratt, Clinical child psychology practice and training: A survey. Vldots of Clinical Child \& Adolescent Psychology, 137(August 2012) et al., "Innovations in Education and Teaching International Rethinking PhD learning incorporating communities of practice Rethinking $\mathrm{PhD}$ learning incorporating communities of practice," Innov. Educ. Teach. Int., 1982.

[8] I. Chabay, "Sustainability and Science Education," in Encyclopedia of Science Education, 2013.

[9] M.E. Rendón-Macías, M.Á. Villasís-Keever, and M.G. MirandaNovales, "Descriptive statistics," Rev. Alerg. Mex., 2016. 